\title{
Introduction to the Research Handbook on Post-Conflict State Building
}

As a conflict ends and the parties begin working towards a durable peace, practitioners and peacebuilders are faced with the abundant possibilities and challenges of building new or reformed political, security, judicial, social, and economic structures. In post-conflict environments, "State-building demands the creation of a durable framework for good governance, strong institutions for peaceful conflict resolution, and the development of, or return to, the rule of law."1 How practitioners can advance those aims - and all the subsidiary and complementary goals intertwined with them-is the extremely complex, yet incredibly important question that lies at the center of this volume.

This volume is part of Edward Elgar's series of Research Handbooks in International Law. Ranging in topics from terrorism to natural resources to cyberspace, each Handbook investigates an intriguing facet of international law or captivating global process shaped by international legal dynamics. This volume, the Research Handbook on Post-Conflict State Building, explores the themes and quandaries that arise during state-building processes that occur after armed conflict. As with the other Handbooks in the series, this volume aims not only to introduce and explain the most fundamental topics in state building, but also to add new insights into ongoing conversations among researchers, lawyers, and advocates engaged in this field.

As an edited volume, the Handbook is able to illuminate post-conflict state building from myriad angles. Each academic or practitioner who contributed a chapter to this Handbook brings a distinctive perspective that allows her or him to astutely weigh in on a particular aspect of the question at hand. Some authors served as diplomats engaged in the negotiations that ended the conflict and the decisions that guided the state-building process. Others served as lawyers advising parties to a conflict on how to navigate the various dynamics in play. Certain authors have spent years studying and teaching about the topics of their chapters. Other authors have storied résumés that showcase the extensive experience they have confronting these issues in the field.

The Handbook is divided into seven parts: (I) Political Infrastructure, (II) Social Infrastructure, (III) Security Infrastructure, (IV) Legacies of Conflict, (V) Rule of Law, (VI) Development, and (VII) Case Studies. Although distinct, the parts build off one another and together produce a holistic, but practical guide for post-conflict state building.

Each of these seven parts of the Handbook includes between two and six chapters that delve into a core element of post-conflict state building falling within that section's topic. In general, these chapters follow a similar organizational structure. First, they introduce and explain the contours of the topic. The chapters then lay out and evaluate the common approaches that have been utilized to address the topic. Finally, they discuss the core challenges that typically face practitioners engaging with the topic before commenting on best practices or lessons learned from comparative state practice that can inform future efforts.

Part I, Political Infrastructure, covers the institutional, governmental, and political components of state building. In post-conflict settings, rebuilding a state's political infrastructure requires setting new guiding rules and processes in order for its institutions to succeed. States 
must reform or reconstruct the weak or dysfunctional institutions of the past that may have contributed to tensions and conflict, but that nonetheless will be essential for future service provision. Without strong and responsive institutions, a state will lack legitimacy and face the prospect of returning to conflict. In "Post-conflict constitution-making," Darin Johnson focuses on ideas of constitutional process and substance in post-conflict scenarios, examining models of constitution-making, constitutional design, and the allocation of state power. Next, "Electoral law and electoral reform" by Jonathan Worboys examines approaches to post-conflict electoral reform, including the selection of electoral benchmarks which must be reached for candidates to achieve victory, the creation of electoral commissions and oversight mechanism, and the reform of electoral procedures and laws. Betsy Popken's "Vetting the public sector" concludes Part I on political infrastructure with a discussion of the goals, legal basis, institutional design, criteria, and structure of post-conflict vetting processes.

Part II, Social Infrastructure, covers efforts to support and develop human and social capital. Conflict between factions within a state exploits differences and deepens social cleavages in a way that leaves lasting effects between groups long after the conflict ceases. Intrastate conflict, in particular, creates exclusive relations that typically undermine group trust and national unity. Rebuilding participatory networks of civic engagement helps bridge vertical and horizontal social relations and facilitate the collective action that drives social reconciliation, reconstruction, and recovery. This part delves into the roles that individuals, civil society, and the media can play in rebuilding a state's social infrastructure in an inclusive and holistic way. In the "Social cohesion and inclusivity" chapter, Milena Sterio and Jessica Levy explore the ways in which post-conflict societies can reunite communities divided by violence, support marginalized populations, and repair the civic trust and social bonds that likely frayed during the conflict. Margaux Day and Christopher Kreutzner's chapter, "Civil society," explains the benefits as well as risks that civil society organizations bring to the state-building process. Finally, this part concludes with Paul Williams and Sophie Pearlman's “Free and independent media" chapter, which investigates the role of media and censorship on democratic transitions, transitional justice, and conflict recurrence.

Part III, Security Infrastructure, covers the processes by which state builders transform structures of military, security, and/or armed resistance in order to reduce the likelihood of conflict relapse and facilitate a transition into durable peace. Working towards both traditional national security objectives and more wide-ranging human security goals, state builders seek pathways towards a security landscape that creates conditions for flourishing rather than a battlefield on which violence predominates. The part begins with "Disarmament, demobilization, and reintegration," a chapter by Christopher Goebel and Jessica Levy in which they discuss how disarmament, demobilization, and reintegration (DDR) strategies have developed as a means through which former combatants can return to civilian lives. Robert Perito's chapter on "Security sector reform" complements Goebel and Levy's discussion of DDR by delving into how security sector reforms that go beyond security assistance can be instrumental in addressing the security challenges facing post-conflict states.

Part IV, Legacies of Conflict, covers the repercussions of violence and instability that a state must face when trying to transition and rebuild. These include broken institutions, accountability challenges, displaced populations, property disputes, and providing reparations to victims, amongst others. Implementing transitional mechanisms to repair civic trust are necessary for a durable peace, but such trust is difficult to come by in post-conflict scenarios where conflict has decimated and divided a population and its institutions. A state must take a holistic 
approach to the implementation of mechanisms, while keeping in mind that their sequence and prioritization must be tailored to the state-specific circumstances. The state is also challenged to strike the proper balance between self-sufficiency and relying on international assistance in order to provide the resources and legitimacy that a transitioning state does not have on its own. Moreover, striving for a durable peace calls for mechanisms that address the legacies of the conflict in ways that meet the needs of vulnerable populations and that the population views as legitimate means to promote healing and prevent conflict recurrence. Hoon's chapter "Transitional justice," examines a number of these mechanisms and the obstacles they face in trying to balance peace, justice, accountability, and reconciliation. Yvonne Dutton focuses on the struggles of and difficulties in addressing displaced populations in her chapter, "Refugees and internally displaced persons." Sandra Hodgkinson's "Property disputes and restitution" chapter investigates dilemmas around the return of, or compensation for, property destroyed, forcibly taken, or otherwise affected by the conflict. Part IV concludes with Brianne McGonigle Leyh's chapter, "Reparations for victims," which explores how individual and collective reparations can provide accountability, victim catharsis, and societal healing in light of atrocities committed during conflict.

Part V, Rule of Law, covers the efforts to build more equitable systems through legal rules and procedures. During armed conflict, rule by force typically prevails, making it appear that violence is the only means to resolve disputes between parties. Transitioning to a durable peace calls for a corresponding shift to rule of law, a paradigm in which legal rules rather than the coercive power of force dictate behavior. Re-establishing rule of law may require significant modifications or additions to the state's judicial landscape, as Jennifer Trahan discusses in her chapter, "Judicial reform and rebuilding." Strengthening rule of law in a post-conflict state also likely involves bolstering the legal landscape around rights and freedoms. Milena Sterio's chapter, "Human rights," traces the evolution and impact of human rights-based approaches to state building. Nikhil Narayan's chapter, "Minority protections," delves into the ways that legal protections for minority groups, in particular, work to combat sociopolitical inequities and other forms of marginalization.

Part VI, Development, covers the physical reconstruction, institutional rebuilding, and economic development that occurs after a conflict to support a state. Post-conflict development is largely focused on economic recovery as growth-oriented initiatives address socio-economic grievances for peace consolidation. However, in a highly fragile and unstable post-conflict economic environment, weak economic governance and unequal economic arrangements can also lead to developmental setbacks. States work to re-establish the foundations for self-sustaining development during the transition from conflict to peace. Part VI analyzes how humanitarian assistance, fiscal arrangements, and economic reform are interdependent mechanisms of post-conflict state building that can promote enduring and sustainable development. This part begins with Elisabeth Dallas and Tyler Beckelman's chapter, "Humanitarian action," which focuses on the role of humanitarian assistance in promoting post-conflict recovery and development. Sârra Tilila-Bounfour's "Re-establishing and reforming the economy" explores models for building robust and resilient post-conflict economies notwithstanding reduced state capacity. Part VI concludes with "Fiscal arrangements," a chapter in which Margaux Day examines how states devolve fiscal power in the state-building process.

The final part, Part VII, Case Studies, amplifies the takeaways of the previous sections by using specific case studies to illustrate the concepts, theories, and assessments provided in Parts I-VI. The case studies cover the state-building processes of six post-conflict envi- 
ronments: Guatemala, Brčko, Kosovo, Afghanistan, Iraq, and Libya. In each, the author provides a detailed description of the events that followed the negotiation of peace, focusing on the mechanisms that facilitated state building and the roles that key actors played in the process. Drawing from these cases, each author concludes by evaluating the overall success or failure of state-building efforts and highlighting lessons learned for practitioners and scholars. The authors also examine the influential role that both the international community and the post-conflict political economy play in the state-building process. The part begins with "Guatemala: an unfulfilled promise," in which Donald Planty discusses the difficulties that mediators faced in negotiating Guatemala's peace agreement and acknowledges various failures of implementation that cause instability to persist. In "Brčko: exemplar or outlier?" Andrew Mann weaves together interviews and commentary of former Brčko Supervisors to explore how the international administration rebuilt this unique District after the violence in the former Yugoslavia. Gëzim Visoka's chapter, "Kosovo: a hybrid negative peace," tackles another region devastated by the conflicts in the Balkans, analyzing how Kosovo's state-building process was shaped by the pressures of statehood in addition to the demands of reconstruction. Richard Kraemer delves further into the tensions between sovereignty and legitimacy in his chapter, "Afghanistan: missteps in reconstruction," as he describes how these state-building aims manifested problematically in the international community's efforts in Afghanistan. Next, Darin Johnson studies the state-building initiatives around Iraq's transitional administration in "Iraq: seeking stability after Saddam." In the final case study, Roland Friedrich and Francesca Jannotti Pecci's "Libya: unforeseen complexities" discusses the obstacles that hindered Libyan state building after the fall of Muammar Qadhafi. Collectively, this part reveals the wide range of ways that state building manifests as well as the frequent failures and disappointments of these processes. Through the six case studies, this part illustrates the challenges of applying the best practices of state building to complex and evolving post-conflict environments.

In sum, this Research Handbook on Post-Conflict State Building offers insights from both the theory and practice of state building. The 24 chapters explore numerous approaches, challenges, and lessons of post-conflict state building through thematic discussions as well as several case studies. It is our hope as editors of the Handbook that this volume will serve as a useful reference for those involved in future efforts to rebuild states in the wake of armed conflict. State building is essential for durable peace. As such, this volume also seeks to demonstrate the importance of successful state building as a tool of conflict prevention and as a template for future global stability.

\section{NOTE}

1. Hallie Ludsin, Peacemaking and Constitution-Drafting: A Dysfunctional Marriage 33(1) U. PA. J. INT'L L. 239, 243 (2011), https://www.law.upenn.edu/live/files/136-ludsin33upajintll2392011.pdf, accessed 19 November 2019. 
Paul R. Williams and Milena Sterio - 9781788971645 Downloaded from PubFactory at $04 / 26 / 2023$ 12:28:54PM via free access 